\title{
SHOCK HUMOR: Zaniness and the Freedom of Permanent Improvisation in Urban Tanzania
}

\author{
MICHAEL DEGANI \\ Johns Hopkins University \\ (D) http:/ / orcid.org/0000-0003-1393-4091
}

[A] key sense of banishment is captured by another German word, used by both Nietzsche and Marx: Vogelfrei, or "free as a bird." To be free as a bird was a bittersweet sort of freedom: while one can do what one wants (for one is not under the compulsion of a state), one can be killed without ramification (for one is not under the care of a state).

—Paul Kockelman

On a Friday night in 2010, the popular television show Ze Comedy is beaming into living rooms and bars across Dar es Salaam. One sketch begins at the desk of a female anchor (played by a man). ${ }^{1}$ We are watching a nightly newscast and she is all exaggerated officiousness. She reports:

The Tanesco Company of Tanzania has issued an announcement to all citizens in the villages, cities, and city centers after determining that there are feki (fake) electricians involving themselves in Tanesco matters in people's homes. The directing manager sent us a memo on the importance of instructing citizens about these fake street electricians, who are known by the name of viwembe (razorblades). I mean, uh, vishoka (hatchets; singular: kishoka). They're very dangerous for you Tanzanians. Regretfully_well, I don't 
want to say too much, but the Ze Comedy cameras have captured one incident that took place out there in the michochoroni (back alleys). We now link up to our reporter who brings us the picture, after which we will return for commentary.

So begins a spectacle in which two "fake" electricians try and fail to fix a minor short, only to be repeatedly shocked. The sketch made a deep impression on me, and I often thought of it while conducting fieldwork on Dar es Salaam's municipal power grid in 2011 and 2012. For electricians, residents, and Tanesco workers, living on - and off - the power grid was a frustrating and difficult experience. But in some moments, it acquired a strange sort of comedy. Residents played seemingly endless cat-and-mouse games with the utility; electricians contrived schemes and deals only to have them backfire; people laughed as they reenacted the dangerous zap of minor shock.

This essay attempts to take such comic moments seriously by treating them as an experiential rendering of the social and political paradoxes of permanent improvisation. It draws on Sianne Ngai's (2012) analysis of zaniness as an aesthetic category. Many Americans will have encountered the zany through film and television figures such as Tom and Jerry, Charlie Chaplin, or Mr. Bean. Many of these same characters populate the imaginaries of African cities like Dar es Salaam. ${ }^{2}$ East African popular culture developed its own version of the zany aesthetic when British colonists disseminated commedia dell'arte plays and Chaplin films through their educational and theatrical institutions (Riccio 2001). Performance troupes blended these influences with indigenous expressive traditions to create what is now known as vichekesho (chuckles): short, farcical, and largely unscripted sketches about scuffling protagonists, of which Ze Comedy is the latest, televised version.

Ngai (2012) persuasively argues that this aesthetic is about constant improvisation or, more specifically, about a permanent entanglement of work and play wrought by capitalism's constant revolutionizing. The original zannis of the commedia dell'arte were modeled after servants of the Italian court - factotums constantly jumping into new roles and situations but struggling to perform them convincingly. Their short-term navigations of the world were thus deeply improvisational in the sense that they were brought into existence by nothing more and nothing less than the doing of it. They channeled the subversive comedy of improvisation, in which one is free from fixed roles or expectations. Yet their status as permanent improvisers gave their comic predicament a tinge of anxiety, 
even desperation. Ironically, their freedom to play around was also a role they were consigned to perform.

While Ngai builds an impressive archive of the zany, she does not engage the literature on what has been variously called the lumpen, the informal, or simply the poor populations of the urban postcolonial global South. The presence of zany characters and situations in cities like Dar es Salaam certainly stands as a corrective to the Eurocentrism of much critical and cultural theory. More importantly, for my purposes, the concept of the zany can be put to productive ethnographic use. It names the way that certain comedic figures and situations I encountered in Dar es Salaam channel the social and political paradoxes of the informal: the way it oscillates between sociopolitical freedom and constraint, the way it generates an ambivalent mix of pleasure and annoyance.

The first section of this essay describes the electrician sketch in more detail and situates the global South and, more specifically, African urban life within broader debates about precarity, affect, and labor. The second part follows electricians and vishoka in their daily improvisations as they race from task to task and struggle to make a living. It shows how their constant improvisations suggest a particular type of zany character defined by a self-conscious performativity. Finally, the third section shows how an improvisational logic extends into the daily operations of state infrastructure. It relays scenes from my fieldwork with Tanesco patrol teams, who were charged with policing irregular power connections and often encountered consumers that tried to evade, bribe, or otherwise fend them off. In the collective zaniness of these encounters, I suggest, one can grasp the underlying paradoxes of citizenship as an exercise in seemingly permanent improvisation.

\section{SHOCK HUMOR}

The Ze Comedy cameras take us to an urban Tanzanian living room, empty but for the glowing television. A baba-father, or man of the house-comes home and surveys the scene. He yells out to his absent children, angry at them for wasting electricity, but he trails off - a colorful music video has caught his attention, and he laughs at the antics on the screen. His reverie is cut short as the power insolently disappears. Scowling, he fiddles with the cables and is rewarded with a zap. "Electronic is power!" he exclaims in English. Holding his hand and cursing, he mutters: "Let me get a youth to come fix this."

In the next scene, a diminutive kishoka ambles in. He wears a plug strip around his neck and a cowboy hat. Despite his flashy outfit, he is a little appre- 
hensive about the task in front of him. "Did you get shocked?" he nervously asks the baba. "No, it was just a little thing," the man of the house assures him. The kishoka musters up his confidence as he leans down. Just as he makes contact, the baba unhelpfully exclaims: "Yes, that's exactly where it is!" Startled, the kishoka jumps back; politely, but testily, he mentions that that kind of thing really raises the pressure of the situation. He is now skeptical and repeats his question: "Did you get shocked?" "No," the baba reassures him impatiently once again, "this isn't a transformer; it was just a small bit of power." The kishoka allows himself to be convinced. "Well, if you didn't get shocked, then it's no problem," he agrees with recovered swagger. The kishoka leans in again to begin. Once again, the baba cannot help but interject, "Right there, that's where the current is," one more time breaking the kishoka's concentration and making him jump back up. For the third time, the jack-in-the-box structure resets. This time the baba remains obligingly silent as the kishoka leans down. Suddenly, the kishoka flies back from shock, doubled over and groaning. The baba harangues him to "quit showboating" (acha majonjo) and "milking the foul like a goalkeeper." The electrician scrambles up and assures the baba that they are dealing with a very serious problem and that he needs to call a friend for help.

In the final scene, the cowboy kishoka's friend swaggers in. He is dressed as an actual soccer goalkeeper, protected by cleats and shin guards, but with pliers jauntily shoved into his belt and headphones clamped over his ears. He grandly announces that there is no need to worry; it is surely only a minor problem and he can fix it. The cowboy explains the situation and then whispers to him, sotto voce: "Brother, I expect that you will give me at least my riziki (daily bread, sustenance) since you came [to this job] through me." The goalkeeper is dismissive. "According to the rules of professional technicians, you must leave and allow me to do my work," he pronounces. They bicker in heated whispers until the baba pulls them apart, frustrated: "Just fix it!"

For all his panache, the goalkeeper is nervous as well. He takes the jack dangling from his headphones and offers it to his friend- "here, plug this in for me," he urges. "No, no, that's a red wire and I've already been shocked by a red wire!" his friend protests. The baba waves his hand dismissively, motioning to the first kishoka. "This one sits in his little body, afraid - he has no blood!" The goalkeeper, we see, is on his own. He delicately places his foot up on the wall and leans in toward the socket strip on the floor. Suddenly, he is shot backward wildly. As he lies dazed on the ground, the other two scramble out of the room, panicked, running into the door Three Stooges-style. We return to the news anchor 
shaking her head: "Just look at what [the goalkeeper kishoka] was wearing! Playing around with electricity without knowing anything. But then, it's not their fault, no. It's the fault of house owners like you all, who hire them instead of professionals. That's why we have unstable power in our cities."

The sketch depicts an encounter with electricity that is perpetually off balance, with residents constantly improvising, yet without much control over the situation. Alternately indignant, entranced, and frustrated, the father's affect is yanked in one direction by his spotty electrical connection and then in the other by the insubordination of his children and the vishoka. The vishoka, meanwhile, are yanked back and forth by the pull of current and currency, willing to risk their bodies and the potential shock the work entails for a few thousand shillings. ${ }^{3}$ They are alternately bickering and reassuring as they try to control the situation, chattering but always with an anxious bravado. Against this diffuse assemblage of interconnected affect, energy, and bodies, the three shocks act as punctuation marks that, for a split second, promise to crystallize the situation, to definitively turn it in one direction or another. But after each body careens to the floor, the antic hum starts back up. All are once again caught up in a teasing rhythm of actions and reactions piling up on themselves.

A number of scholars have engaged the trope of improvisation as a way to understand creativity and method (e.g., Pandian 2015; Hegel 2017). Tim Ingold $(2009,97)$ argues that improvisation is nothing less than the "form-giving" process of life itself, its lines of flight crisscrossing into a world-making texture. And yet here we are confronted with lines of flight that do not so much weave as collide and bounce off each other. How might we account for an improvisational unfolding that is not form-giving but, in some sense, as Ngai $(2012$, 231) asserts, "form-obliterating"? This also means to ask how we might historicize improvisation itself, tracing its forms and aesthetics in relation to particular social and political processes.

To begin answering these questions, I would suggest that the sketch depicts a fundamentally zany scene. "In their purest form," Daniel Harris (2000, 117) observes, zany comedies are "structureless journeys through worlds of dangerous and volatile objects. Every prop, every character is . . . a potential projectile.” And yet for all its acrobatics, zaniness tends to give off more light than heat. Indeed there is "something impotent and reactive about the zany's incessant activity," an "undercurrent of desperation" (Ngai 2012, 187). 
Ngai tracks zaniness across high and low culture, from Friedrich Nietzsche and Jacques Derrida's manic deconstructive prose stylings to gender-bending films like Mrs. Doubtfire or The Full Monty, with their specifically post-Fordist concerns about the feminization of labor. At root, however, the zany's extroverted performativity expresses a type of work that has accompanied capitalism since its early modern inceptions. In sixteenth-century commedia dell'arte, a zanni denoted the servant character and was based on peasants near Milan and Venice who escaped war and droughts in search of work as itinerant laborers. Zannis, then, were jacks-of-all-trades who made themselves available for whatever task might be required. What Ngai $(2012,191)$ calls their "veritable theme song" belongs to Figaro in The Barber of Seville, who sings: "Ready to do anything / night and day / always on the move . . . swifter and swifter I'm like a thunderbolt, I'm the factotum of the city." The necessity of improvisation also highlighted a reflexive link to theater, both in that factotums had to play whatever role they were given and in that acting was, itself, an early form of precarious gig work staged by bands of traveling players.

Through improvising, then, the zany (as both character and situation) thus indexes an open-ended, performative kind of labor. In some deep Austinian sense, all labor is performative in that it must enact its own conditions of possibility (Lee and LiPuma 2002). As Karl Marx (1990, 200) observed long ago, becoming a commodity is a salto mortale, a leap of faith. Its exchange value is not pregiven but only emerges retrospectively, after the buyer has paid for it (and the seller has agreed to part with it). Yet Marx's account of capitalism narrates the emergence of infrastructures and institutions that format this leap so as to make it perform more reliably. Primitive accumulation and enclosure movements disembedded peasants from their land and funneled them to the disciplinary spaces of the school and factory to ensure that they had nothing to sell but their labor power. Hence, while working for a wage has a performative dimension, it does not quite feel performative. The historical contingency of extracting surplus value is veiled within the discipline of capitalist relations and thus naturalized, given a taken-for-granted quality that ultimately extends to the "empty homogenous time" (Benjamin 1968, 261) of capital itself (see Chatterjee 1999, 131).

Much of the scholarship on contemporary precarity dwells in the heterotopic gaps and residues of this system, attending to superfluous populations that cannot be absorbed into the labor force or afforded biopolitical care. In many places, this is rightly narrated as abjection and abandonment (Povinelli 2011). With cautious optimism, other accounts point to the ways in which subjects find them- 
selves free to improvise niches in global supply chains, aligning whatever resources (affect, bodily capacities, social relations) they have at their disposal to deliver a competitive advantage (Tsing 2015). Ngai cites the sociologists Luc Boltanski and Eve Chiapello's (2005, 110-11) observation that the quintessential sort of work under this new spirit of capitalism is the transient, entrepreneurial project, a term that, as we will see, suggestively links back to the experience of the projectile.

Indeed, Ngai argues that the preindustrial zany prefigures the relentlessly expansionary tendencies of a postindustrial capitalism no longer regimented by the infrastructures of mass employment. Zanies were, in a sense, the first permanent workers with nothing to sell but their labor power. But they contrast with the classic industrial proletariat, which experiences its social constraints and social freedoms as bifurcated along a gendered public/private distinction: as producers regimented on the factory floor and then as consumers enchanted by the play of advertising and commodities. But in late capitalist milieus, where many workers are neither fully employed nor fully unemployed, and where they are not only commodities but also self-marketing ones, the experiences of work and play are combined in a series of entrepreneurial projects unmoored from institutional supports. Postindustrial work thus merges with a long history of explicitly performance-oriented occupations that include domestic servitude, women's unpaid labor, and culture-industry work. In all of these situations, producer and product are precariously entangled in what is now baldly called "human capital."

To these examples of para- and postindustrial project work we might add the small-scale entrepreneurs of postcolonial cities such as Dar es Salaam. In many parts of the world system, a bazaar-style economy that mixes commerce and social relations has long existed (Geertz 1978). Here, small-scale traders have survived through performance in a socially thick marketplace and against the predations of the colonial and postcolonial state (Clark 1988). As generations of scholars have learned, no truly satisfying sociological term exists for these subjects of the "informal economy" (Hart 2006). As James C. Scott $(2012,55)$ says of such artisans, peddlers, and market women, "they are neither fish nor fowl, they may be poor, but they are poor capitalists."

The undecidable nature of such poor capitalists is well reflected in their scholarly treatment. Most contemporary accounts react to a high-modernist contempt rooted in Marx's (1994) dismissal of the lumpenproletariat as little more than a grab bag of disjointed opportunists, spasmodically following whoever might ply them with wine and sausages. In his socialist manifesto, the Arusha Declaration, Tanzania's first president Julius Nyerere (1968, 30) similarly proclaimed 
that the "energies of the millions of women in the villages and thousands of men in the town which are at present wasted in gossip, dancing and drinking, are a great treasure which could contribute more to the development of our country than anything we could get from rich nations." The message here is clear: such populations are not properly working; they are at play. Hence they are sociopolitically constrained, pathetically tied to their own desires and thus unable to act collectively or contribute to modern development.

Against such sentiments, proponents of neoliberal empowerment have adopted a rhetoric that would dignify things like gossip and self-expression as social capital to be mobilized (see Elyachar 2010). Without going quite this far, Africanist urban ethnographers have attended to the creativity of urban life as "a kind of improvisation under conditions of adversity" (Ferguson 2015, 94; see also Mbembe and Nuttall 2004; Simone 2004). In many respects, this sensibility can be traced back to the notion of the informal economy, Keith Hart's 1970s-era attempt to reconcile abstract development models with streets that were "teeming with life, [with] a constantly shifting crowd of hawkers, porters, taxi-drivers, beggars, pimps, pickpockets, hustlers - all of them getting by without the benefit of a real job" (Hart 2006, 24). Here the message is just the opposite: such populations are in fact working. Hence they are sociopolitically free, uncaptured by a dirigiste state and harboring potential for alternative modes of development.

To each set of propositions, zanies might well respond with that classic principle of improvisational comedy: "Yes, and!" Effectively freed from the standardized wage labor or peasant subsistence wrought by state developmentalist schemes, they are free to do anything. Free to do anything, they find themselves doing a bit of everything-hedging, calculating, keeping their options open, but rarely with any definitive resolution. In other words, zaniness aesthetically expresses the paradoxical freedom of the informal economy, piling up improvisations until they blur into a generalized, teeming movement without distinction or referent.

This paradoxical freedom also helps explain why zaniness as an aesthetic is both funny and grating to its spectators. It is certainly true that buying and selling have long been associated with playful humor. Mikhail Bakhtin (1984, 34) notes that commedia dell'arte is an outgrowth of the medieval carnivalesque, which itself is rooted in the historical experience and "language of the marketplace." Marketplaces "consecrate inventive freedom, [they] permit the combination of a variety of different elements and their rapprochement” (Bakhtin 1984, 34). There thus exist dense historical and conceptual links between fairs and markets and 
their ritual suspension of normal proprieties; in such spaces, one is free to play with one's words, intentions, and identity. Bakhtin insists on the utopian possibilities of this space, wherein seemingly opposed categories - strangers and familiars, praise and insults, gifts and thefts - are all reconciled in a bawdy, regenerative laughter. The carnival brings the high low and renders the foolish holy. It is thus a space of transgression and critique, puncturing the pretensions of officialdom.

But the zany is a kind of parody of the utopian fair/liminal marketplace. Its exaggerated hustling specifically embodies the capitalist market, whose constant revolutionizing creates a permanent play frame. Thus, if the Rabelaisian marketplace liberates bodies from feudal propriety, the zany body is laced up tight, propulsive, anxious, electric - constantly doing and acting. While this has a certain comedic potential, the effect underscores that for all his or her movement, the zany is stuck. As the Ze Comedy sketch suggests, the zany's presence does not so much relieve or liberate a stuffy situation as whirl everything into a frenzied mixture of exuberance and exhaustion, pleasure and punishment. Where the metacommunicative frame of the carnivalesque is "this is play," the zany situation seems to ask, is this play? ${ }^{4}$

In its endless, self-consuming fun, the zaniness of labor echoes other historical situations in which social license is exaggerated to the point that its comedy acquires an uncertain edge. In his seminal account of the postcolony, for example, Achille Mbembe (1992) points out how the routine, banal qualities of the Commandement's buffoonery renders it a kind of psychic violence. It induces a reactionary laughter pointedly at odds with the affirmative, joyous laughter that Bakhtin emphasizes. In a mixture of subversion and impotence, the zany might be seen as a kindred postcolonial figure; where Mbembe offers a vision of the African state as a kind of permanent carnival, the zany suggests the African metropolis as a permanent marketplace generated in its wake. Where Mbembe highlights the grotesque overconsumption of the Commandement, we might probe the zany overproduction of the proverbial "little man" of African life, the way he exhausts those who would discipline him and, in turn, himself.

The remainder of this article elaborates these points through examples and encounters from my ethnography of Dar es Salaam's power grid, beginning with vishoka electricians. On the one hand, vishoka exemplify "the freedom of the citythe anonymity, the possibility of reinventing oneself, an encompassing possibility of social license" (McGovern 2010, 72). This is a freedom from socioeconomic claims pressed by rural kin, for example, or a freedom from the social relations 
of wage labor. At its best, working as a kishoka entails the freedom to earn money through heterogeneous projects — different jobs, different clients, and different roles - all potentially convertible into money. Vishoka have license to be "entrepreneurs in the literal sense of 'bringing together' the valuation repertoire" (Guyer 2004, 98), with its range of gains. Hence, as Sasha Newell $(2012$, 4) has described for youth in Abidjan, "to work" (travailler) is above all a kind of play - a series of games or performances, with their bluffs and possibilities.

On the other hand, the freedom to improvise means that, in some sense, one must keep improvising. Any deal, score, or trade is structurally disconnected from the next, so that the performative work of bringing the valuation repertoire together must always begin anew. The building of reputation, social trust, and expertise are all so many strategies to domesticate this fundamental instability, albeit without ever resolving it. Hence, caught somewhere between the uncertainty of the marketplace and the predictabilities wrought by reputation or skill, the days of the vishoka are a paradoxical repetition of dissimilar tasks. This can make for ambivalently zany comedy.

\section{FREE IMPROVISATION}

The value of freedom is something that electricians often expressed to me. Consider the case of a fundi (handyman) named Samueli. Samueli started his career by lucking into a job through his neighbor, a Tanesco employee who recognized Samueli's knack for working with his hands. Samueli was paid Tsh. 5000 per day to install new electrical service lines in houses that had completed the application process. After four years, Samueli was part of a cohort of eighty temp workers who did not have their contracts renewed - officially because they had not passed their secondary educational exams. Afterward, Samueli reconstituted his career mtaani (in the street). He began working as a kishoka fixer, wiring houses without a license and liaising with friends still working at Tanesco to expedite applications for new connections. Now, he explained:

I live a good life . . . yes, the days are incomparable, there's Monday and then there's Tuesday, but on the days when it pleases God, I can make Tsh. 200,000, even Tsh. 600,000. I can do wiring for up to 1,000,000. And with that, even if I spend the rest of the month just sitting and not working, I'm still doing better than when I was working inside the company. There the boss loads you with work, where sometimes you don't leave until nine at night or ten, sometimes you're at the site until morning for Tsh. 5,000. 
If you protest to the boss, "why are you having us work for more time than we're getting paid?" he'll say “don't come into work tomorrow.” They just fire you. It's much better now than in the company.

In contrast to wage labor, working as an entrepreneur offers the dream of social autonomy. Consider how an electrical contractor named Felix recalled his training in a sort of primal scene, laughing how as a boy his father beat him for tinkering with a circuit box:

In primary school, I pulled quite a sweet stunt at home. I opened a switch in the house. When I reconnected, it shocked me. I was looking at it like, “ah, why did I just get shocked?" I didn't understand that electricity shocks you. I reconnected it and got shocked again, because I was using a knife. When my father saw what I was doing, he really beat me, but that didn't stop me. I was asking myself, what the devil happened there? I asked my friend about it, and he said: "That electricity will kill you!" I became a little timid, but it wasn't overpowering.

As a budding electrician Felix risked his father's punishment to entertain his curiosity. This attitude condenses what Mike McGovern (2010, 56-57) calls "entrepreneurial capture," an agentive ethic widely documented across sub-Saharan Africa since its insertion into the capitalist world system nearly five hundred years ago. In folklore and popular culture, for example, the "mutant hero" (De Boeck 2000) of Afromodernity - a mix of cowboy, hunter, soldier, and other masculinist figures of action - has exemplified the bravado conversion of sometimes illicit or dangerous opportunity into gain. In a similar vein, Dar es Salaam youth have historically had their own "cult of the cowboy" (Burton 2001). Such figures in turn form part of a wider network of symbolic contrasts. In East Africa, they are associated with fluid substances like blood and money, with their powers of transmissibility and connection, and stand in contrast to the density and particularity of bone, with its powers of containment and preservation (Beidelman 1997). Felix's childhood encounter with electricity intimates this embodied tension between improvisation - an unlegislated and free-form connectivity - and the punitive, policing functions of paternal authority.

As suggested above, this tension can also map onto the distinction between waged work, with its hierarchical relations of command and procedure, and entrepreneurial labor, with its lateral negotiations. A Tanesco worker once wove these associations together in the following comment to me: 
There's something called self-confidence [kujiamini] that bedevils us. And even today it entered. I went to cut the power and was supposed to wear gloves, but I just went like this [he holds up his bare hands]. But that electricity . . . [shakes his head]. And why? Because of self-confidence. It's an issue that needs to be addressed educationally, that you shouldn't have excessive self-confidence.

The background to these comments was a discussion of vishoka electricians, who are often said to be uneducated and overly confident - that is, reckless. But whereas salaried work turns on restraint, working as a street electrician for hire incentivizes some measure of "self-confidence," even if the conditions are less than safe. The baba's accusation that the cowboy kishoka "lacks blood" speaks to this idea. Self-confidence, here, is related to blood's ability to flow and mix, to weave new relations between people and things. The anthropological ear may hear resonances with the concept of bricolage, which involves the willingness to dive into a situation and assemble something from the elements at hand (Lévi-Strauss 1966). The magic of self-confidence, then, is the way it performatively actualizes potential: a new circuit is completed, a new skill acquired, a new relation with a client forged.

Many electricians are not as lucky as Samueli. As mafundi ya mtaani (street handymen) or, as they are alternately called, mafundi vishoka, they get by with small-scale repairs that are not much different from Felix's initial foolhardy encounter: jerry-rigging an urban landscape filled with electrical odds and endswire and batteries, copper and plastic. As the mafundi of the sketch learned, this polymorphous environment of potential connections may prove uncooperative. Incessant contingencies vex their work, forcing them to move in a set of steps logically corresponding to the nature of the problem they confront. An electrician must acquire this part before he can work on that one; he must complete a first task before he can move on to a second one. Each task, moreover, can suffer its own shifts in availability of materials or from knowledge deficits. Finally, the electrician must also balance multiple jobs at different levels of completion, ones that will generate different levels of revenue and that embed different levels of personal connection. With certain kinds of competitive firms, these variables are more or less rationalized, so that the consumer experience has a measure of predictability (Geertz 1978). Registered contractors in Dar es Salaam, for example, have offices and formal contracts to this end. By contrast, it is said that the street electrician's office is mfukoni, in his pockets. 
Sometimes, unsurprisingly, these logistical convolutions can work to an electrician's advantage. Artisanal craft, after all, begets craftiness, and self-confidence is but a short jump to the realm of the confidence artist. As my friend Ally once grumbled to me: "The only honest fundi is a kinyozi, a barber." Why? Barbers cut your hair in one shot, and you see the result immediately. Its visibility and temporality is that of the instantaneous commodity exchange. It has none of the veils, elongations, or delays that tend to make exchanges feel personal, in the manner of a gift. With a haircut there are no intermediary steps, no elaborate supplies or shortages thereof, no knowledge asymmetries between buyer and seller. Indeed, many residents related stories of seemingly well-installed wiring that broke down or turned out faulty, or electricians that had taken money for parts and then kuingia mitini, "disappeared into the trees."

For their part, electricians complained to me of underpayment and unreasonable demands from their clients. In general, I found them to be like any commercial operators in that (to mix metaphors) most would try to cut corners without burning bridges - a calculus that is not without its own emergent logic (Degani 2017). One friend, for example, told me he employs an old handyman's trick of leaving spare tools at his different worksites. This almost perfectly rides the line between hustling in the sense of performing to the best of his abilities and hustling in the sense of merely performing (that is, of being only a "fake electrician”). It allows him to move between jobs while assuring anxious or pushy clients he will soon return. Moreover, it is a testament to the realities of smallscale electrical work, in which technicians are free to pilot their own livelihoods and yet yoked to an array of shifting circumstances, customer indignations or desires, supplies and possibilities. Whether an electrician's hustle is oriented toward honest exertion or a quick score (an ideal-typical division suggested, for example, in the respective attitudes of the cowboy and goalkeeper vishoka), his continuous improvisation can foster a certain zany sense that he is at once free and constrained, a sense that is often codified in the form of being a particular kind of character.

When I told a friend in Dar es Salaam about my fieldwork with electricians, he chuckled and suggested I meet Issa. Issa was a neighborhood electrician who provided the useful but not-quite-licensed service of clambering up utility poles and balancing loads on transformers. He had once famously injured his leg while jumping down from one in an attempt to run away from the police. He was, my 
friend said grinning, "a real kishoka." When we finally did sit down at a local bar, Issa did not disappoint. He arrived theatrically, announcing that he was tired of getting shocked - the last one was enough to swear him off utility poles altogether. Working on a transformer, he had had the misfortune to grip his pliers "poorly," where there was no rubber insulation; after that, he said laughing, "only God himself knows what happened to me; all I know is I came to and suddenly had to pee.”

Minor shocks are inevitable, Issa went on to reflect, evincing the same touch of pride as Felix did (cf. Winther and Wilhite 2015). They are, he told me, the mark of any electrician whose work entails mambo ya practical, the practical problems of the handyman, and not mambo ya theoretical, the abstract problems of engineers. Echoing the refrain of the original factotum Figaro, Issa went on to define vishoka like himself as those street electricians who are willing to "do anything" for a client, to take on any job even if it should involve tasks not strictly legal or within their field of competence. And like Figaro, Issa was a man for whom the distinction between action and reaction, freedom and constraint, was comically precarious. He likened the jolt of current to a soccer ball shooting off the cleat, and his own constant movements around town to a skittish crow, flying from branch to branch.

In fact, during our conversation, Issa stopped in the middle of his animated explanations to answer his phone: a woman wanted to know if he could fix a short. "I'm a bit far," he said, "let me hop on a motorcycle taxi and I'll be right there." Actually, he smirked as he hung up, the woman was right down the street, but this way he could charge extra for nauli, travel fare. Without much ado, he jumped up and walked away, leaving his beer and half-eaten chicken on the plate. Fifteen minutes later he came back, having decided not to do the work. The household's other tenants were out and wouldn't be returning until morning, and the most money the woman could muster was Tsh. 4,000. And besides, he was getting drunk and in no mood to get shocked again.

Unlike well-paid Tanesco engineers or technicians, Issa is indeed a kind of bricoleur. He responds to, and with, whatever elements are at hand, and attempts to assemble them to his advantage. How much does one motorcycle taxi ride cost? Is it measured in miles? Gallons of gas? What might have convinced him to work a little tipsy and wait another day for payment? A closer social relationship? A less equal one? Issa's livelihood is thus a kind of improvised performance. He must rise to the occasion, in all its social and technical complexity. But precisely because of this unruly complexity, there is no guarantee that its elements can be 
properly aligned. Issa could not have predicted that another job would present itself in the middle of dinner, nor could he have predicted that his client would delay payment. The only available option was to keep improvising - in this case, to return to the bar and finish his meal. This is perhaps why Issa turns to the language of birds and soccer balls_- projectiles careening around the city, unencumbered by any particular situation but constrained by all of them. In a similar vein, Claude Lévi-Strauss $(1966,16)$ notes in passing that bricolage originally referred to some sort "extraneous movement" in sporting, "a ball rebounding, a dog straying or a horse swerving from its direct course to avoid an obstacle." This older meaning captures the blurred boundaries between seizing a situation and being seized by it, since a swerve is precisely both at once. When that swerve is drawn out and elevated to social theater - when an entire character feels like one continuous series of swerves, for example - we can feel the zaniness of entrepreneurial freedom. We experience constant improvisation taken to its logical conclusion - a frenzy of movement as such, divorced from any particular efficacy.

It is perhaps not surprising that shocks poetically evoke continuous improvisation's ambivalent sense of action sans efficacy. Consider the following story a mechanic friend told me. One day, while hanging out in his garage, he pointed to a tangle of fraying wires and asked if I knew what would happen were I to grab one. He explained that he once mistook a live wire for a neutral one, holding his arms out and mimicking the jerky contraction of his hands around the uninsulated copper. The forces multiplied as his quick-thinking friend wrapped his hands in a T-shirt and attempted to pry him loose, only to have the current pass into him. After a moment, both tumbled backward, clanking their heads on the iron bars that closed the small space. While I chuckled uneasily at the violence and danger of the story (and the arms-length tangle of wires that precipitated it), his laugher seemed to echo the convulsive shock itself. As the Ze Comedy players captured so well, minor shock galvanizes the body, simultaneously liberating and constricting it, reducing it to an autonomic response yet animating it with a surging intensity.

Zaniness thus manifests the paradox of continuous improvisation. For the lucky and skilled, improvisation can be an opening up of the social field and its opportunities. The city remains a preeminent site of freedom and life-building; vishoka like Samueli and Issa can be in control of their working day. Yet this control comes at the cost of predictability. It asks its residents to be factotums on call, disposed to any opportunity, whether or not they are exactly qualified to pursue it. It guarantees residents work in general but not in particular, and 
this sends them running around in circles, sometimes literally. ${ }^{5}$ Is this social freedom or constraint? The joke is that it is both.

Issa, I suspect, grasps this joke all too well. Indeed, in many ways Issa was himself a comedian, improvising a performance about the failure of improvisation and thus partially mitigating that failure; he did not get the job, but he did get a few self-mocking wisecracks in (and thus perhaps charmed a guileless anthropologist buying him dinner). Issa was a "real kishoka" in exactly the same way American English speakers call someone a "real character"-someone who has fully internalized his or her role as a performer in everyday life, who is always switched on and onstage and therefore alternately amusing and aggravating.

There is a rich tradition of such ambiguous characters in East African popular culture, constantly reacting to unpredictable circumstances, their labored improvisations bound up in the politics of both class and colonialism. The origins of vichekesho skits have been traced to Zanzibari "street vendors selling water and peanuts during colonial times. These people were usually from rural areas and illiterate, and in order to attract customers, they exaggerated their dress and behavior" (Riccio 2001, 135). Adopting influence from Chaplin, as well as early modern comedies by Shakespeare and Molière, they often centered on "satirical misunderstandings of African servants in front of their British masters" (Shule 2010, 52), their contortions both amusing and evidence of their low status. In the postcolonial era, terms such as mswahili likewise mobilize an ambivalent mixture of amusement and derision. Conflating the negative associations of coastal, African, or even national identity, a "Swahili" person is a poor urban resident without proper employment who is constantly scrambling through life (Brennan 2006, 409). During my fieldwork, friends would teasingly admonish each other to acha mambo ya Swahili (quit it with the Swahili business), sometimes wisping their fingers across their lips to suggest garrulous bullshitting. They would also impute the historically "African" settlements (uswahilini) of the city to be full of quarrelsome and often fumbling gossips and schemers (cf. Lewinson 2006). For those characters, whose survival depends on nothing more and nothing less than continuous improvisation, the very notion of a stable character itself becomes a zany farce. And, recapitulating social theory's own undecided stance toward the informal, this farce oscillates between contempt and sympathy. Residents can laugh at the fact that no matter how hard zany characters work or scheme, they never get very far, and at the fact that their indiscipline generates a certain anarchic chaos in its wake. 


\section{THE ZANINESS OF PATROLS}

Historically, the fictional and real zany characters of Dar es Salaam are poor residents looking to survive through forms of entrepreneurial capture, only to find themselves caught up in a Swahili-style scramble. Part of the reason for this scramble, however, lies in the colonial and postcolonial state's repeated campaigns to tax, repatriate, or otherwise police them, and their equally concerted attempts to evade these operations. Despite formal political and economic changes, this general dynamic has remained remarkably consistent. As Aili Mari Tripp (1997, 1) has shown, the great open secret of Tanzania's liberalization in the late 1980s and early 1990s was that it merely ratified the ongoing noncompliance of ordinary people, who often merrily and quite performatively outwitted state agents.

Improvisation is thus not only a mode of livelihood but also, insofar as it intersects with state governance, a mode of citizenship. Residents often cultivate an entrepreneurial attitude toward the state's biopolitical infrastructures of control and provision. They cut corners and elect to take njia panya, the rodent's route, alternately provoking or evading the nuisances, burdens, and obstacles of legality and formal regulation. The catch, however, is that one is never fully off the clock in such a mode. Issa's improvisations set off a cycle of move and countermove, pinging and spiraling him about the city. When this cycle is sufficiently drawn out or raised to a certain pitch of intensity, the sheer zaniness channels its underlying social paradox - the sense that one is actively performing (their livelihood, their citizenship), but so permanently performing it that it threatens to lose coherence and direction. In this final section, I examine the political paradoxes of permanent improvisation by considering the zany as an aesthetic of infrastructure.

Infrastructures have both symbolic and affective dimensions that exist beyond their technical properties (Larkin 2013). Electricity networks in particular have long functioned as the "tentacles of modernity" (Winther and Wilhite 2015), bringing light to countrysides and placing populations on grids of state legibility. In recent years, electrical infrastructures have also served as instruments for imparting fiscal discipline and self-responsibility (von Schnitzler 2016). All of these elements are generally in play in Tanesco's daily operations, which mix idioms of consumer discipline with a civic commitment to paying one's fair share for the collective good. For their part, residents often invoked their expectation that the state adhere to its own disciplinary standards and provide reliable service. Indeed, Tanesco is routinely glossed as mali ya umma, public or state property, in a phrase 
that literally translates to something closer to "collective wealth." It stands in some basic way for reciprocity between citizen and state.

Despite these discourses of discipline and reciprocity, the grid exemplifies a more entrepreneurial relation to urban infrastructure common throughout the global South. By the mid-2000s, electricity had grown more expensive and less reliable in Dar es Salaam, giving rise to a thriving informal economy of electricity whose sociotechnical dynamics sit somewhere between flouting a lugubrious state and drawing its resources into local neighborhoods. Vishoka, as we have seen, might be hired for quick, cheap repairs, but also, more audaciously, to reconnect lines, tamper with meters, or create switches that toggle between metered and unmetered electricity. Significantly, the largest constituency for outright theft comes from high-volume power consumers. With only a few lights or fans, poorer households' consumption patterns are usually too low to be worth the risk or effort of active theft; they are far more likely to get disconnected for debt and nonpayment. By contrast, light industries, bars, and wealthier households find more intensive electricity use central to business and pleasure. As one wealthy patriarch once told me, "the cord cuts where it is thinnest"; for those with the resources to do so, the grid was a logical site to be entrepreneurially worked or gamed.

These arrangements incited their own countermeasures. Since at least the 2000s, Tanesco has sent out a variety of patrols on a daily basis, as well for what they called special "exercises and operations" to inspect and/or disconnect households for theft, debt, or other irregularities. During my fieldwork, I accompanied one such patrol, a Revenue Protection Unit (RPU), as they tried to access, inspect, and enforce the legality of their power connections. To my surprise, these encounters often tilted less toward the disciplinary than toward the zany. As I wrote in my field notes at the time, my prose mimicking the somewhat frenetic encounters they described: "To determine if a customer had done anything wrong was to cut through a maze of excuses, of inherited debts, other actors not on the scene, of absentee landlords and tenants late on the bills, of misplaced documents and technical malfunction, of spatial ambiguities, of ignorance feigned and real." Like other African cities, Dar es Salaam was replete with cat-and-mouse games between consumer and utility (Larkin 2008, 246).

The games would begin on arrival. In wealthier households, meters are often locked behind a compound gate or thick door and a series of social-legal assertions. Again and again on RPU patrols, domestic servants, guards, and relatives would assert that they did not have the authority to let us in, as the house did not legally 
belong to them. Although the homeowner is ultimately responsible for the meter, such dependents were often very nervous about interacting with us. They rightly understood that they would be held responsible for admitting the RPU team into the house in the first place. Hence we were treated to many exaggeratedly solemn declarations that we could not possibly be admitted. This was a rather inane bit of theater, but one with a convincing set piece and mood lighting: an iron gate or concrete wall physically enclosing the space. In one such house, an inspector discovered that a meter was rigged so that two of its three phases were not recording the power consumed. As she was finishing writing out the disconnection form in duplicate, the truck arrived out front. I followed her out of the compound to help get the ladder. She glanced back, jumped a little, and told me to remain right where I was. "Why?" I demanded. I was instantly suspicious that some bribery proffer was afoot. "Because," she answered, "if we both walk past the gate, they'll probably lock us out."

Once we did get in the door, RPU patrols could turn zany thanks to the tenacity with which customers stuck to flimsy responses, betrayed only by their own sheepish smiles. One day we were called to examine a large, very wealthy compound whose owners were away traveling. This left the dependents - a brother-in-law, gardener, and house girl - to deal with us. A common way to test for meter tampering is to have the customer switch on all electricity-consuming objects in the house and measure the meter's output relative to an RPU voltage recorder. An amazing comedic dialogue ensued. The home's four air conditioners could not be switched on because, well, each of their remotes were missing, we were told. And all the musical equipment on the top floor - that was broken too. What about an iron? "No," the house girl informed us, "no one uses an iron here." In Dar es Salaam this is a rather astonishing claim.

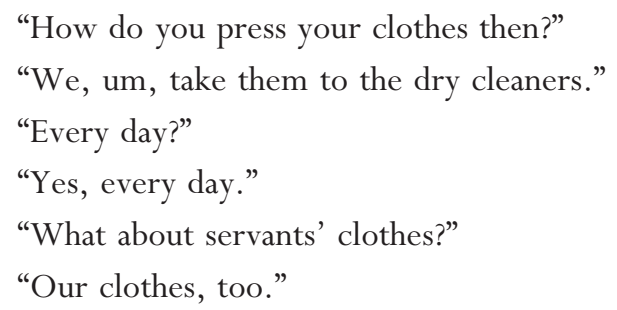

We switch tacks. An inspector sees that the bracket, where the cable connects to the house, looks a little odd, but at the moment our truck does not have the one ladder that's being shared between the two RPU teams working the area. 
There is a ladder chained to the fence, so we ask the gardener if he can unlock it. "I don't have the key," he promptly replies.

"Well, then, where is it?"

"It's probably inside."

"Can you go in and get it?"

"I've never gone inside the house."

"Never?"

"Never."

"How long have you been working here?"

"Three years."

"Three years?"

"Look," he said, laughing, "ask me to get the jembe (hoe), no problem. Anything else, I don't know."

When all else failed, residents would proffer bribes. Bribes, with their euphemisms and uncertainties, are explicitly improvisational and as such perhaps especially prone to comedy. During rounds in the commercial center of Kariakoo, for example, a team of RPU inspectors disconnected a hotel for an elaborate setup that could toggle between metered and unmetered power, one that included selling stolen electricity to the house next door. The team decided that the resident was guilty by extension and that his wire was to be cut. Smiling, and presumably unaware that I understood Kiswahili, the resident proclaimed his ignorance and implored that surely they could work something out. Partly for my instructional benefit, the inspector answered: "And about the money that Tanesco has lost because of your actions? How will that be recovered?" "Oh that," he answered, laughing, "well, it's already gone, no use worrying about it." At this point I started laughing myself. The tenant, seeing that I had been following along, started laughing with me-we all knew the jig was up. In fact, a few days later we happened to pass each other at the Tanesco office- he had surely come to deal with that very disconnection. We both did a double take and started laughing all over again.

The zaniness of the RPU patrols lies in the way residents launched themselves into spontaneous evasive maneuvers with a mixture of agility and impotence, never quite evading so much as delaying their impending disconnection. As such their antics proved both amusing and irritating for the inspectors. By the same token, however, RPU teams could occasionally be made to look the fool. However temporarily, residents could give them the runaround, thwart some 
particular advance or, as in the case of the renter in Kariakoo, undercut their officious performance of bureaucratic authority. Indeed, sometimes the work of a single disconnection required a comically large expenditure of energy relative to the RPU team's daily quota of households. And this relative impotence held true more broadly; no matter how many households the inspectors cut, they were all too aware that the disconnection sheet would continue to grow, and that many households would simply surreptitiously reconnect. This exercise in mutual vexation, I think, formed part of the laughter I shared with the Kariakoo renter who had been cheerfully buying stolen electricity.

There are interesting implications to the cat-and-mouse games that flourish at the junctures of the power lines connecting consumer to utility. Tanesco hails its customers as citizens, as part of a collective responsibility toward a national project and social order. What instead transpires is a more agonistic, negotiable version of this social contract in which power connections are liable to breakdown or increase in expense, provoking households to pursue various shortcuts or clever rearrangements. The result is that basic service (from the state) and basic legibility (of citizens) are locally variable and collectively constrained. Zany situations allow us to feel the way that governance and perhaps the city itself becomes seized by this paradox, rendering it a collectivity defined by its inability to act in concert. In true bottom-up, free-market fashion, a zany power grid is one in which there are only ever temporary winners and losers, temporary connections and disconnections. Energy infrastructure, which should withdraw into the backstage of daily life, becomes a site of incessant activity, worry, argument, and indeed performance.

\section{CONCLUSION}

Slavoj Žižek (1999) observes that as cultural modes, comedy and tragedy involve a kind of immortality, albeit the opposite ones. In the tragic predicament, the hero forfeits his terrestrial life for the Thing, so that his very defeat is his triumph, conferring onto him the sublime dignity, while the comedy is the triumph of the indestructible life - not of the sublime immortality of the tragic hero, but of the very vulgar, opportunistic, terrestrial life. Which is why the ultimate comic scene is that of a false death: say, the proverbial scene of the solemn funeral with all the relatives gathered, crying and praising the deceased, when, all of a sudden, 
the allegedly dead awakens (he did not really die, after all) and asks what the hell is going on, what's all the fuss about?

The kinds of back-and-forth on RPU patrols that I detail above get at this fundamentally comedic, stubborn survival. At the wealthy compound, the indefatigably straight-faced excuses persisted, irreverently, beyond any semblance of plausibility. The resident in Kariakoo's attitude toward Tanesco's lost revenue reminds one of the man who wakes up at his own funeral: it's not gone, just departed - what's the use in mourning? The comedy of improvisation lies in this unexpected burst of indestructible life where we expect suffocating form, a salto mortale into the next encounter, workday, or milieu. But (as the original acrobatic zanni attests) the zany is all bursting and leaping. Its intensified irreverence is not just funny but manic, not just joyous but vaguely regimented. It is a comic aesthetic about, in some sense, the limits of comedy, the point at which what Žižek calls "vulgar, opportunistic, terrestrial life” begins to race around in a permanent limbo-where situational adaptability becomes the defining feature of one's character. Electricity, which is at once vital and mechanical, which can never stop moving, is perhaps the zany medium par excellence. As the Ze Comedy sketch illustrates, it can channel a shock that pushes lighthearted comedy into something more tetchy and ambiguous.

The relevance of the zany for Sianne Ngai (2012) is precisely this ambiguity, one that she suggests is appropriate for a postindustrial milieu in which heroic genres such as the sublime or the beautiful no longer have the same purchase. To call something zany is to find its superfluity sort of amusing and sort of irritating. Whether or not this general claim about aesthetics under capitalism holds, I do find the zany to be a suggestive concept with which to think through the informal economies of the global South. The freedom of entrepreneurial improvisation has been routinely underestimated by colonial and postcolonial high modernists who cannot stand the disorder of the marketplace and the urbanity it fuels. The ability to make one's own money, to control one's own working day, and perhaps to even cut a deal on things like one's household power supply all give urban life its characteristic sense of play and possibility. As Michael Watts (2005, 182) observes: "Uncertainty, turbulence, unpredictability, chronic shifts, and unanticipated innovations - Charles Baudelaire's 'mouvements brusques' and 'leaps and jolts of consciousness [soubresauts de conscience]' . . . serve as a basis for the African city's sameness-as-worldliness.” 
Still, in conducting fieldwork on Dar es Salaam's power network, I have come to suspect this formulation might lend too much grace to the somersaults. It misses their anxious comedy, their spiritual proximity to undignified scrambling. As often as not, vishoka, residents, and state officials take the "leaps and jolts" of the urban life in which they are caught and render them not as ballet, but as a farcical bricolage of wheeling and dealing. They play the Swahili Figaro, thunderbolts zigzagging through the city, their succession of moves and countermoves evoking freedom and constraint in the same careening whirl.

\begin{abstract}
This essay explores scenes of zany comedy in Dar es Salaam, Tanzania, across three sites: a television sketch about repeated electrical shock; the careers of freelance electricians known as vishoka; and encounters between residents and power utility inspectors. Drawing on the work of Sianne Ngai, as well as long-term ethnographic research, the essay argues that zaniness manifests the structural paradoxes of entrepreneurial populations that have alternately been described as the lumpen, the informal, or simply the urban poor. Specifically, it argues that such populations are often consigned to permanent improvisation and that this engenders a social freedom that, in some respects, remains indistinguishable from constraint. The zany can thus critically nuance portraits of livelihood and citizenship practices in urban Africa by bringing their freedoms and constraints into the same frame. [comedy; improvisation; precarity; informal economies; electricity; African urbanism]
\end{abstract}

\title{
NOTES
}

Acknowledgments Research for this article was funded by the National Science Foundation, the Social Science Research Council, and the Wenner-Gren Foundation. I am deeply grateful to Mike McGovern and Naveeda Khan for their long-running encouragement and feedback over the course of its development. Special thanks goes to Anand Pandian, whose own improvisational sense of anthropological possibility served as a guiding inspiration. I also wish to thank Cultural Anthropology's editors, Dominic Boyer, Cymene Howe, and especially James Faubion, for their support and wisdom, as well as three anonymous reviewers for their thoughtful readings and critical improvements. Petra Dreiser and Marcel LaFlamme were indispensable in shepherding the manuscript through the copyediting and production process. Finally, thanks and love to Natalie Hung for her careful edits and for putting up with my own zaniness.

1. The sketch can be accessed online at https://eastafricantube.com/view/7400/ze-comedy-mafundi-vishoka.

2. Jamii Forums, Tanzania's major message board and social-media site, has numerous threads and videos devoted to Charlie Chaplin, Mr. Bean, Buster Keaton, and other zany comedians. For an example, see http://www.jamiiforums.com/threads/kwa-wapenzi-wa-comedy-yupi-mkali-kati-charlie-chaplin-na-mr-bean. 938370.

3. At the time of my fieldwork and of this sketch, the exchange rate was about Tsh. 1600 to US\$1.

4. Here I draw on Clifford Geertz's (1972) classic account of “deep play," but also on 
Mike McGovern's (2010) discussion of Gregory Bateson and play frames in the context of violence and political theater in Côte d'Ivoire.

5. Compare Danny Hoffman's $(2011,104)$ discussion of "production in general and without distinction" in the context of West Africa's Mano River War.

\section{REFERENCES}

Bakhtin, Mikhail

1984 Rabelais and His World. Translated by Helene Iswolsky. Bloomington: Indiana University Press. Originally published in 1965.

Beidelman, Thomas O.

1997 The Cool Knife: Imagery of Gender, Sexuality, and Moral Education in Kaguru Initiation Benjamin, Walter Ritual. Washington, DC: Smithsonian Institution Press.

1968 "Theses on the Philosophy of History." In Illuminations: Essays and Reflections, edited by Hannah Arendt and translated by Harry Zohn, 253-64. New York: Schocken Books. Originally published in 1940.

Boltanski, Luc, and Eve Chiapello

2005 The New Spirit of Capitalism. Translated by Gregory Elliott. New York: Verso. Originally published in 1999.

Brennan, James R.

2006 "Blood Enemies: Exploitation and Urban Citizenship in the Nationalist Political Thought of Tanzania, 1958-75.” Journal of African History 47, no. 3: 389-413. https://doi.org/10.1017/S0021853706001794.

Burton, Andrew

2001 "Urchins, Loafers and the Cult of the Cowboy: Urbanization and Delinquency in Dar es Salaam, 1919-61.” Journal of African History 42, no. 2: 199-216. https://doi.org/10.1017/S0021853701007861.

Chatterjee, Partha

1999 “Anderson's Utopia.” Diacritics 29, no. 4: 128-34. http://www.jstor.org/ stable/1566381.

Clark, Gracia

1988 Traders versus the State: Anthropological Approaches to Unofficial Economies. Boulder, Colo.: Westview Press.

De Boeck, Filip

2000 "Borderland Breccia: The Mutant Hero in the Historical Imagination of a Central African Diamond Frontier." Journal of Colonialism and Colonial History 1, no. 2: Degani, Michael 1-43. https://doi.org/10.1353/cch.2000.0010.

2017 “Modal Reasoning in Dar es Salaam's Power Network.” American Ethnologist 44, Elyachar, Julia no. 2: 300-314. https://doi.org/10.1111/amet.12480.

2010 "Phatic Labor, Infrastructure, and the Question of Empowerment in Cairo." American Ethnologist 37, no. 3: 452-64. https://doi.org/10.1111/j.15481425.2010.01265.x.

Ferguson, James

2015 Give a Man a Fish: Reflections on the New Politics of Distribution. Durham, N.C.: Duke University Press.

Geertz, Clifford

1972 “Deep Play: Notes on the Balinese Cockfight." Daedalus 101, no. 1: 1-37. http://www.jstor.org/stable/20024056.

1978 "The Bazaar Economy: Information and Search in Peasant Marketing." American Economic Review 68, no. 2: 28-32. http://www.jstor.org/stable/1816656.

Guyer, Jane I.

2004 Marginal Gains: Monetary Transactions in Atlantic Africa. Chicago: University of Chicago Press. 
Harris, Daniel

2000 Cute, Quaint, Hungry, and Romantic: The Aesthetics of Consumerism. New York: Da Capo Press.

Hart, Keith

2006 "Bureaucratic Form and the Informal Economy." In Linking the Formal and Informal Economies: Concepts and Policies, edited by Basudeb Guha-Khasnobis, Ravi Kunbar and Elinor Ostrom, 21-35. New York: Oxford University Press.

Hegel, Christine

2017 "Improvisation." In "Collaborative Analytics," Theorizing the Contemporary series edited by Dominic Boyer and George E. Marcus, Cultural Anthropology Hoffman, Danny website, July 27. https://culanth.org/fieldsights/1176-improvisation.

2011 The War Machines: Young Men and Violence in Sierra Leone and Liberia. Durham, N.C.: Duke University Press.

Ingold, Tim

2009 “The Textility of Making." Cambridge Journal of Economics 34, no. 1: 91-102. https: / /doi.org/10.1093/cje/bep042.

Larkin, Brian

2008 Signal and Noise: Media, Infrastructure, and Urban Culture in Nigeria. Durham, N.C.: Duke University Press.

2013 “The Politics and Poetics of Infrastructure." Annual Review of Anthropology 42: 327-43. https: / / doi.org/10.1146/annurev-anthro-092412-155522.

Lee, Benjamin, and Edward LiPuma

2002 "Cultures of Circulation: The Imaginations of Modernity." Public Culture 14, no. 1: 191-213. https://doi.org/10.1215/08992363-14-1-191.

Lévi-Strauss, Claude

1966 The Savage Mind. Chicago: University of Chicago Press. Originally published in 1962.

Lewinson, Anne S.

2006 "Domestic Realms, Social Bonds, and Class: Ideologies and Indigenizing Modernity in Dar es Salaam, Tanzania." Canadian Journal of African Studies 40, no. 3: 462-95. https://doi.org/10.1080/00083968.2006.10751402.

Marx, Karl

1990 Capital, Volume 1. Translated by Ben Fowkes. New York: Penguin. Originally published in 1867.

1994 The Eighteenth Brumaire of Louis Bonaparte. New York: International Publishers. Originally published in 1852 .

Mbembe, Achille

1992 "The Banality of Power and the Aesthetics of Vulgarity in the Postcolony." Translated by Janet Roitman. Public Culture 4, no. 2: 1-30. https://doi.org/ 10.1215/08992363-4-2-1.

Mbembe, Achille, and Sarah Nuttall

2004 "Writing the World from an African Metropolis." Public Culture 16, no. 3: 34772. https: / / doi.org/10.1215/08992363-16-3-347.

McGovern, Mike

2010 Making War in Côte d'Ivoire. Chicago: University of Chicago Press.

Newell, Sasha

2012 The Modernity Bluff: Crime, Consumption, and Citizenship in Côte d'Ivoire. Chicago: University of Chicago Press.

Ngai, Sianne

2012 Our Aesthetic Categories: Zany, Cute, Interesting. Cambridge, Mass.: Harvard Nyerere, Julius K. University Press.

1968 Ujamaa: Essays on Socialism. New York: Oxford University Press. 
Pandian, Anand

2015 Reel World: An Anthropology of Creation. Durham, N.C.: Duke University Press. Povinelli, Elizabeth A.

2011 Economies of Abandonment: Social Belonging and Endurance in Late Liberalism. Durham, N.C.: Duke University Press.

Riccio, Thomas

2001 "Tanzanian Theatre, From Marx to the Marketplace." TDR/The Drama Review 45, no. 1: 128-52. https://doi.org/10.1162/105420401300079095.

Scott, James C.

2012 Two Cheers for Anarchism: Six Easy Pieces on Autonomy, Dignity, and Meaningful Work and Play. Princeton, N.J.: Princeton University Press.

Shule, Vicensia

2010 "Beyond Socialism: Tanzanian Theatre, Neoliberalism, and Foreign Aid Complexity.” PhD dissertation, Johannes Gutenberg-University Mainz. http:// nbn-resolving.de/urn:nbn:de:hebis:77-35409.

Simone, AbdouMaliq

2004 For the City Yet to Come: Changing African Life in Four Cities. Durham, N.C.: Duke University Press.

Tripp, Aili Marie

1997 Changing the Rules: The Politics of Liberalization and the Urban Informal Economy in Tanzania. Berkeley: University of California Press.

Tsing, Anna Lowenhaupt

2015 The Mushroom at the End of the World: On the Possibility of Life in Capitalist Ruins. Princeton, N.J.: Princeton University Press.

von Schnitzler, Antina

2016 Democracy's Infrastructure: Techno-Politics and Protest after Apartheid. Princeton, N.J.: Princeton University Press.

Watts, Michael

2005 “Baudelaire over Berea, Simmel over Sandton?” Public Culture 17, no. 1: 18192. https://doi.org/10.1215/08992363-17-1-181.

Winther, Tanja, and Harold Wilhite

2015 "Tentacles of Modernity: Why Electricity Needs Anthropology." Cultural

Žižek, Slavoj Anthropology 30, no. 4: 569-77. https://doi.org/10.14506/ca30.4.05.

1999 "Laugh Yourself to Death: The New Wave of Holocaust Comedies." Lacan Dot Com, December 15. http://www.lacan.com/zizekholocaust.htm. 